\title{
Valuation Methods of Sports Companies ${ }^{1}$
}

\author{
Zbigniew Pawlak ${ }^{1}$, Andrzej Smoleń ${ }^{2}$
}

\author{
${ }^{1}$ Warsaw School of Economics, Poland \\ ${ }^{2}$ Josef Pilsudski University of Physical Education in Warsaw, Poland
}

KEYWORDS valuation methods of real estate, sport joint stock companies

\section{Introduction}

In colloquial speech company value is a feature or a set of features specific to a person or things deciding about its virtues (e.g. moral, artistic etc.). Generally speaking value is a philosophical term. The question of value in this meaning is dealt with by a branch of philosophy called axiology (philosophy of values). Talking about value in specific terms we always have in mind one of the following types of values: value of assets, economic, technical, artistic, moral, historical, functional, market, scientific, intellectual, cultural values. Enterprise value is the maximum price a potential buyer is willing to pay for a business or the price for which the previous owner is willing to sell his business (Szczepkowski 2001, p. 11).

The valuation of businesses including sports companies is necessary and sometimes vital to: carrying out purchase/sale transactions of an enterprise or shares (interest) in companies, carrying out restructuring procedures, mergers and break-ups of businesses, determining the issue price of shares

\footnotetext{
${ }^{1}$ The text has been written as a part of the research program DS 131 - "Management of real estate in sport, tourism and recreation" financed by the Polish Ministry of Science and Higher Education.
} 
and value of stock coming from share capital increase, and also determining the value of subscription rights, securities for obligations (drawing of credits and loans, issue of bonds), determining premiums for property insurance purposes, determining remuneration for the management boards and employees (Jaki 2004).

In the market-driven economy demand for businesses' valuations is very high. It is partially permanent (e.g. property insurance, determining the level of wages of management and personnel), partially periodical (e.g. securing of obligations), and in other cases (e.g. mergers, damages) occasional (Herman, Szablewski 1999, p. 106).

Many entities have their eye on the value of businesses: business owners, potential buyers of businesses, their parts, shares and interests, managements boards and personnel of businesses, business partners, competitors, financial institutions (banks, insurance companies, investment funds), inland tax revenue offices, capital market analysts, consultants.

During the valuation of sports companies the valuation covers assets, rights to assets (e.g. ownership title, perpetual usufruct) and people (e.g. in case of contestants' transfers). The valuation may cover simple assets (machinery and equipment), complex (e.g. real estate, land, buildings), or very complex (e.g. entire companies, trademarks of renowned sports clubs etc.).

Though the value of sports business is expressed in financial terms this is not an unambiguous notion and cannot be quantified precisely. Its value can be determined using a ballpark estimate. The value of a business, especially a company/corporation, is determined in the sports by many drivers both of intrinsic and extrinsic nature. A special feature of company value is the impact exerted by the appraising person. The company value is not objective, but is always an expression of strictly personalized preferences of a stakeholder, especially the owner and the buyer (Malinowska 2001, pp. 30-31). Thus it can be assumed beforehand that the quest for objective company value will end in a fiasco.

The company valuation performs several material functions.

- advisory (decision making) function - provides information to the buyer or seller of a company to take a decision,

- argumentative (substantiating) function - allows substantiation of the expected price for the company for the transacting parties, viz. buyer and seller,

- intermediary (mediatory, negotiating) function - provides grounds for negotiations between transacting parties, viz. buyer and seller,

- information function - meets informational needs of the parties interested in growth prospects and financial standing of the company,

- protective function - used by managers to protect themselves in case of disputes over the decisions taken about the company (Nita 2007, p. 56).

This paper aims to present sports company valuation methods, including in particular companies/corporations.

\section{Methodological approach to valuation of sports companies}

When valuing sports companies one can encounter a lot of theoretical and methodological difficulties. These entities may be valued using various methods, depending mainly on the objective of valuation, assumptions made, company status. Company valuation methods can be classified into four categories, reflecting four basic approaches to company valuation:

1) assets-based valuation method - the value of assets is estimated; this is understood as the total value of company assets, 
2) income-based method - the income value is estimated; this is understood as total clear income that can be generated by the company,

3) market-based valuation method - market value is estimated; this is understood as the hypothetical price that can be charged for the company selling it on the free market,

4) hybrid method - mixed value is estimated; this is understood as the resultant or arithmetic mean (ordinary, weighted) of assets-based, income-based and market-based value.

The assets valuation method assumes that the company value equals the value of its assets less its debts. The basis for estimating the company assets is usually the book value of the assets, with adjustments made to bring them closer to market prices, or the assets replacement costs. The asset valuation method is used primarily for the pricing of businesses with low profitability and also businesses that are undergoing winding up proceedings or bankruptcy proceedings. The disadvantage of the asset valuation method is the failure to account for a number of intangible assets of the company making up its so-called goodwill, which includes: trademark, organisational structure, human factor, network of regular customers and suppliers etc. Thereforeit is not advisable to use this method for the valuation of thriving companies, since far too often it leads to the underestimation of company value.

For the purposes of valuation of profitable companies that generate income for their owners the most suitable approach is the income-based valuation method, which involves the estimation of the total current value of the future income of the company. The most proper yardstick for company income are cash flows, since they already account for debt incurred and its repayment, so it is not necessary to deduct indebtedness from total cash flows. The income valuation method should not be used to estimate the value of businesses that have a large assets base, but which for certain reasons generate low income.

The market-based valuation method assumes that the company valuation can be made on the basis of market information about prices realized for buy/sell transactions for entire businesses or prices of shares (interest) in companies. The best information database for the transaction price is the stock exchange, where at every trading session the current prices of shares in public companies are quoted. It has to be remembered that exchange trade applies to minority shareholding in companies, and consequently the product of the current price of company shares and the number of issued shares does not reflect the actual market value of the company. The share belonging to majority shareholding, giving control over a company, certainly has higher value than the share in a minority shareholding.

If the prices of companies obtained applying asset-based method, income-based method and market-based method are too varied (differences in the range of $25 \%$ are regarded as such), then it is possible to use the mixed valuation method for the company. The mixed valuation method is in fact not a new methodological approach, since it uses the results of valuation obtained from the three conventional approaches listed above. The mixed approach involves result-averaging (ordinary or weighted arithmetic mean) or the calculation of resultant value based on special formulae, using assetbased, income-based or market-based valuation method outputs.

When determining the final valuation result the following principles are applied:

1) if the results obtained using various methods differ slightly (max. 25\%), then using the results the ordinary or weighted arithmetic mean can be calculated:

$W p=\frac{M+D+R}{3} \quad$ where:

$W p=\frac{2 \cdot M+D+3 \cdot R}{6}$

$\mathrm{Wp}$ - company value 
$\mathrm{M}$ - company value obtained using asset-based method

$\mathrm{D}$ - company value obtained using income-based method

$\mathrm{R}$ - company value obtained using market-based method

2 ) if the company values obtained using different valuation methods vary significantly (above 25

$\%$ ) then the following steps have to be taken:

- to analyse the adequacy of valuation methods applied to the case,

- to reject the extremely high (low) result,

- the remaining valuation results use to calculate the arithmetic mean.

Additionally it should be noted that when valuing a company it can be viewed from two angles: a specific investor that may have a specific interest in the acquisition of the company, or an abstract investor we have no idea about. In the former case the investment value of the company is estimated, whereas in the latter case - the fair market value. As a rule the first one is the ceiling of transaction price for which one can sell or buy the company, while the second is a floor. Thus the company value range is arrived at where the ultimate transaction price should be, which is always an outcome of negotiations carried out by the interested parties and the strength of their arguments rather than an outcome of valuation exercise.

The valuation of sports companies using various valuation methods is presented in Table 1.

Table 1. Valuation methods applied to professional sports clubs

\begin{tabular}{lll}
\hline$\#$ & $\begin{array}{l}\text { Approaches to valuation } \\
\text { of sports companies }\end{array}$ & Methods \\
\hline I. & Assets-based approach & $\begin{array}{l}\text { book value (net assets) } \\
\text { adjusted book value (adjusted net assets) } \\
\text { replacement } \\
\text { liquidation } \\
\text { capitalized profit }\end{array}$ \\
II. & Income-based approach & - Discounted Cash Flows (DCF) \\
III. & Market-based approach & - $\begin{array}{l}\text { Comparable worth method } \\
\text { market multipliers (multiples) }\end{array}$ \\
IV. & Mixed & - German \\
\hline
\end{tabular}

Source: own analysis

\section{Asset-based valuation methods applied to sports companies}

When valuing sports companies using assets' net book value method the following pricing formula is used:

\section{$\boldsymbol{W}_{A N E}=\boldsymbol{A}-\boldsymbol{P O}$}

$W_{A N E} \quad-$ net value of recorded assets (net book value )

A $\quad-$ total assets value

$P O \quad-$ value of third party liabilities (provisions for liabilities and liabilities)

The net value of assets is equivocal to the company equity.

When valuing company using net adjusted assets method the following pricing formula is applied:

$W_{A N W}=A_{W}-P O_{W}$

$W_{A N W}$ - value of net adjusted assets 
$A_{W} \quad$ - value of total adjusted assets

$P O_{W} \quad$ - value of adjusted third party liabilities

The net adjusted assets valuation method requires a detailed review of each item on the assets and liabilities side of the company balance sheet. The method boils down to adjusting the individual assets and liabilities to the real value. For instance, when adjusting the book value of individual assets the following detailed methods can be used:

a) land - market-based method,

b) buildings - market-based method, replacement method, income-based method,

c) equipment and machinery - replacement method, market-based method,

d) means of transport - market-based method, replacement method,

e) inventory - market-based method,

f) receivables - market-based method etc.

The replacement method is used for fixed assets pricing. The formula used to determine replacement value of a single fixed asset is as follows:

$W_{O N}=W_{O B} \cdot(1-Z f) \cdot(1-Z m)$

WON - net replacement value (value of a fixed asset accounting for its physical and moral wear)

WOB - $\quad$ gross replacement value (value of a new fixed asset)

$Z f \quad-\quad$ physical wear and tear rate

Zm - obsolescence rate

Below we present a case study applying the replacement valuation method. "Avia" SA sports club has a complex of training and office buildings with total floor area of $3,400 \mathrm{~m}^{2}$. The appointed professional appraisers determined the gross replacement value of $1 \mathrm{~m}^{2}$ of floor area to be at the level of PLN 3,250. At the same time the appraisers determined the physical wear and tear of the facilities to be $45 \%$, and obsolescence rate to be $0 \%$. Given the above assumptions the replacement value of the facility complex amounts to:

$W_{\text {ON }}=3400 \cdot 3250 \cdot(1-0.45) \cdot(1-0)=P L N 6077500$

In the company valuation liquidation method two formulae are used: one for a business's winding up procedure if the business has gone bankrupt, the other in other non-bankruptcy cases of liquidation. When valuing the company for the purposes of a winding up procedure it is assumed that the value of assets (bankruptcy estate) is the total of prices achievable through selling off company assets. In this case the following valuation formula is applied:

$W_{L}=\sum_{i=1}^{n} C_{r i}$

WL - company liquidation value

$n \quad-\quad$ number of assets marketable through a sell-off process

$i \quad-\quad$ number of a consecutive asset

Cri - $\quad$ hypothetical price (selling off value) achievable through the sale of asset number $i$

During company valuation for the purpose of non-bankruptcy winding up the following pricing formula is used: 


$$
W_{L}=\sum_{i=1}^{n} C_{r i}+N-D+P-K
$$

WL $\quad-\quad$ company liquidation value

$n \quad-\quad$ number of assets marketable through a sell-off process

$i \quad-\quad$ number of a consecutive asset

Cri - $\quad$ hypothetical price (selling off value) achievable through the sale of asset number $i$

$N \quad-\quad$ company receivables

$D \quad-\quad$ company debts

$P \quad-\quad$ estimated revenues during winding up period

$K \quad-\quad$ estimated costs during winding up period

\section{Income-based valuation methods applied to sports companies}

When valuing profitable sports facilities or entire sports companies it is possible to apply the profit capitalized valuation method. Under this method the average planned annual net profit generated by a facility (or by the entire company) is divided by an assumed capitalization rate of this profit. The profit capitalized valuation formula is as follows:

$$
W_{d}=\frac{Z_{n}}{r}
$$

Wd - company income value

Zn - average forecast annual net profit

$r \quad$ - assumed capitalization rate of net profit

$\frac{1}{r}-$ desirable equity return period (in years)

$0 £ r £ 1$

The valuation of the facility (company) using the above method is equivocal to multiplying the average planned net profit by assumed equity return period.

Here is an example. "Tornado" SA sports club has an indoor swimming pool, which was valued using the profit capitalized valuation method. For this purpose a business plan was developed that showed average annual net profit at the level of PLN 110,000. The assumed return on this type of investment amounts to 8 years. Thus, the income value of the facility is PLN 880,000.

$W_{d}=\frac{110000}{0.125}=880000$

The company that is a going concern and generates income is valued primarily by appraisal of clear cash income that will be generated for the owner, i.e. the Discounted Net Cash Flow Method. If we were able to forecast all future cash flows that the company could generate, its value would be equal to the total value of discounted cash flows to the present value counted ad infinitum. Since the value of money changes over time, cash flows in consecutive years in the future are not comparable. Discounting of future cash flows allows us to learn their present value, and thus to simply add them up. The formula used by the DCF valuation method is presented below:

$$
a_{t}=\frac{1}{(1+d)^{t}} \quad W p=\sum_{t=1}^{\infty} \frac{P P N_{t}}{(1+d)^{t}}
$$


$W p=\sum_{t=1}^{\infty} a_{t} \cdot P P N_{t}$

where:

$W p$ - company value

$t$ - another year of company operations

$d$ - assumed discount rate

$a_{t}-$ discount coefficient for year $\mathrm{t}$

$P P N_{t}-$ net cash flows in year $\mathrm{t}$

In reality the company management is able to project future net cash flows only for a couple of years. Therefore the above formula for valuation of income-based value of the company has to be modified. The company value is then calculated as the sum of two components. The first component includes discounted cash flows for the period of feasible projection of financial results, while the second component - the so-called residual value (also called continuation value) - includes discounted flows for the last year of projection. The best method to calculate the residual value is to apply income formula. Assuming that the average clear cash flow after the projected period will hover around the level close to the previous year, we may determine the residual value using a simple capitalization method, dividing the expected mean annual cash balance by the assumed discount rate. Thus the company valuation formula will look as follows.

$$
W p=\sum_{t=1}^{m} a_{t} \cdot P P N_{t}+a_{m} \cdot R V \quad R V=\frac{P P N_{m}}{d}
$$

where:

$W p$ - company value

$m$ - number of years for feasible projection of company financial performance

$P P N_{m}$ - net cash flows in the last projected year (treated as mean annual future net cash flows)

$R V$ - residual Value

The discount rate applied to discount future cash flows to the present value reflects the cost of capital employed, which is equivocal to the level of expected rate of return on investment into the company. It should be added that the discount rate must have higher value than the interest rate of safe capital investment e.g. deposits with reputable banks or purchases of Treasury bonds. The difference between the discount rate and the interest rate of risk-free investment is a premium for taking a business activity risk. If this premium were not there nobody would invest in companies, being satisfied with more favourable, safer bank deposits or even safer Treasury bonds. When operations are financed with equity the discount rate equals the cost of equity, and in the case of employing mixed sources of funding (equity and third party capital), it can then be expressed using the weighted average cost of capital (WACC) formula.

$u_{w}+u_{o}=1$

where:

$d_{m}$ - discount rate for funding activities from mixed sources

$r_{w}$ - cost of equity

$u_{w}$ - percentage of equity (decimal percentage)

$r_{o}$ - cost of third party equity

$u_{o}$ - percentage of third party capital (decimal percentage) 
For company valuation using net discounted cash flow method the following formula is applied:

$$
\begin{array}{ll}
W_{d}=\sum_{t=1}^{5} a_{t} \cdot P P N_{t}+a_{5} \cdot R V \\
W d \quad \text { - income value } \\
t \quad \text { - studied year } \\
a t & \text { - discount factor for year } t \\
P P N t & \text { - net cash flows for year } t \\
R V & \text { - residual value }
\end{array}
$$

For company valuation additional formulae are used:

$$
d=r+i+s
$$

$$
\begin{array}{ll}
d & \text { - discount rate } \\
r & \text { - actual interest rate for risk-free investments } \\
i & \text { - inflation rate } \\
s & \text { - business risk premium }
\end{array}
$$

$$
R V=\frac{P P N_{5}}{d}
$$

Below is a case study on valuation using income-based method for "Krak" SA sports club. The current owner wanted to sell his club to an interested institutional investor. For this purpose he decided to value income generation capacity of the club for the purposes of negotiations with the investor. Based on the analysis of club activities to date the owner developed a business plan for a period of 5 years that shows positive net cash flows (PPNt). For the purposes of estimating the club's income generation capacity the discount rate was assumed at the level of $10 \%$. The calculation of the club's income value is presented in Table 2 below.

Table 2. Illustrative income-based valuation of "Krak" S.A sports club using net discounted cash flow method

\begin{tabular}{llllll}
\hline Item & Year & & & & \\
& I & II & III & IV & V \\
\hline PPNt & 1234892.00 & 1242980.00 & 1250890.00 & 1260944.00 & 1274220.00 \\
at & 0.909 & 0.826 & 0.751 & 0.683 & 0.621 \\
at*PPNt & 1122629.09 & 1027256.20 & 939812.17 & 861241.72 & 791190.37 \\
$\square$ at*PPNt & & & & & 4742129.55 \\
RV & & & & & 3478090.00 \\
a5*RV & & & & & 2159620.24 \\
Wp & & & & 6901749.79 \\
\hline
\end{tabular}

Source: own analysis

The computations made show that the income value of "Krak" SA sports club amounts to PLN 6901749.79 . 


\section{Market-based valuation methods for sports clubs}

The comparative worth method boils down to the company valuation based on known prices of buy and sell transactions involving similar companies. The simplest formula used in the marketbased comparative worth method is the ordinary and weight arithmetic mean formula. The ordinary arithmetic mean can be applied when the sale prices of at least two companies similar to the company under valuation are known.

$$
W_{R}=\frac{C_{1}+C_{2}+\ldots+C_{n}}{n}
$$

WR - company market value

$c 1, c 2 \ldots c n \quad-$ known sale prices of very similar companies

$n \quad-$ number of comparable companies

When the companies sold have a different size to the company under valuation the average weighted transaction price formula can be applied. For instance we carry out valuation of "Warta" S.A sports club based on known prices of purchase and sale transactions involving two other clubs, of which one is double the size of the club under valuation and was sold for the total amount of PLN $14,500,000$, whereas the second one is 1.5 times larger than the club under valuation and was sold for PLN 11,900,000. Consequently:

$$
W_{R}=\frac{14500000+11900000}{2+1.5}=\frac{26400000}{3.5}=7542857.14
$$

It is also possible to value the company based on information about share prices of listed companies using market multipliers (multiples) method. A prerequisite for such valuation is that companies from the same industry have to be listed on the stock exchange. The market value of a listed company can be presented as the product of outstanding shares and current price.

$$
W_{R G}=L_{a} \cdot K_{a}
$$

$W_{R G} \quad$ - market value of a listed company

$\mathrm{La} \quad$ - number of outstanding shares

$\mathrm{Ka}$ - share price

The market-based valuation formula for a non-listed company using stock exchange information (i.e. market multipliers method) is based on the knowledge of market multipliers and is as follows:

$$
W_{R N}=M r \cdot E
$$

where:

$W_{R N} \quad$ - market value of a non-listed company

$\mathrm{Mr} \quad$ - market multiple

$E \quad-$ economic quantity characterizing company under valuation relevant for a certain multiplier 
For the listed companies every session 2 market multiplier is calculated:

1) price/earnings $(\mathrm{P} / \mathrm{E})$ ratio - expressing the ratio of daily price to the earnings per share,

2) price /book value $(\mathrm{P} / \mathrm{BV})$ ratio - expressing the ratio of daily price to the book value.

To value a profitable company not listed on the stock exchange based on exchange information, the P/E ratio multiplier has to be used. In the case of a non-profitable company the P/BV ratio will be better. We can examine this based on the illustrations presented below.

Two profitable football clubs are listed at the stock exchange. Their P/E ratios are 12.4 and 16.9 respectively. Based on this information income-based valuation of another football company has to be made given that its net profit amounts to PLN 2,450,000. To make computations it is necessary to use two equations:

$W_{R N}=12.4 \cdot 2450000=30380000$

$W_{R N}=16.9 \cdot 2450000=41405000$

Then based on the outputs from two equations the arithmetic mean has to be calculated. The computations made show that the market value of a non-listed company amounts to PLN 35,892,500. A similar valuation exercise is carried out for companies with low profitability (or which are unprofitable) using $\mathrm{P} / \mathrm{BV}$ ratio multiplier.

\section{Valuation of sports companies using a mixed method (German method)}

The mixed valuation method is used to draw conclusions from company valuation, when outputs from different valuation methods are varied a great deal. Most frequently the mixed valuation formula is used:

$\mathrm{Wm}=\mathrm{M}+\mathrm{G}$

where:

$\mathrm{Wm}$ - mixed value

M - assets-based valuation method (e.g. using net adjusted assets method)

$\mathrm{G}$ - company goodwill (reputation understood as company capacity to generate income)

It is assumed that if the company is profitable then the buyer should pay the price arrived at using assets-based valuation method + G. However, if the company is not profitable, the buyer should pay the price arrived at using assets-based valuation method - G.

The G parameter (goodwill) is determined most frequently using the so called German formula, which is as follows:

$G=0.5(D-M)$

where:

G $\quad-\quad$ company goodwill

$D \quad$ - $\quad$ price arrived at using income-based valuation

$M \quad$ - $\quad$ price arrived at using assets-based valuation 
The application of the mixed valuation method is presented in the example below. The "Motor" SA sports club was valued using income-based method and its value is PLN 4,780,000. Meanwhile the assets-based valuation method showed the value of PLN 7,930,000. Now the club's value will be calculated using mixed method. After data has been applied to the formulae the results are as follows:

$$
\begin{aligned}
& G=0,5(4780000-7930000)=P L N-1575000 \\
& W m=7930000-1575000=P L N 6355000
\end{aligned}
$$

Thus the value of "Motor" SA sports club obtained using a mixed method is PLN 6,355,000.

\section{Summary and conclusions}

- The valuation of sports companies is indispensable during company buy and sell transactions, restructuring processes, determining premiums for the purposes of property insurance.

- For the valuation of sports companies four approaches are possible i.e. assets-based, incomebased, market-based and mixed valuation approaches. Under each approach there are specific company valuation methods. In the case of assets-based valuation approach there are two methods: book value, adjusted book value, replacement and liquidation. In case of income-based approach the capitalized profit and discounted cash flow valuation methods can be used. With regard to market-based approach the comparative worth and market multiples valuation methods are used. The mixed valuation approach is not a new methodology. Such a formula is used when the output prices from company valuation using assets-based, income-based and market-based approaches vary too much, and differences in values exceed $25 \%$.

- The value of sports companies cannot be determined precisely, but merely estimated using the aforementioned methods.

- The knowledge and skilful application of valuation methods to sports companies should be regarded as one of the prerequisites for effective management of sports companies from a management accounting perspective. The valuation methods should be incorporated into educational curricula, training courses and skills development schemes for sports managers.

\section{REFERENCES}

Herman, A., Szablewski, A. (Ed.) (1999). Company Value Management.Warsaw: Poltext Publishing House.

Jaki, A. (2004). Company Valuation. Premises, Procedures, Methods. Crocow: "Oficyna Ekonomiczna" Publishers.

Malinowska, U. (2001). Company Valuation Methods in Polish Realities. Warsaw: DIFIN Publishers.

Nita, B. (2007). Valuation and Company Value Management Methods. Warsaw: PWE Publishers.

Szczepkowski, P. J. (2001). Learning the Value of Own Business. Warsaw: JPiS Publishers. 